\title{
Reprezentacje biedy i wykluczenia społecznego w tabloidach i mediach głównego nurtu
}

Pomimo że współczesne kapitalistyczne społeczeństwa konsumpcyjne
uporały się w znacznej mierze z problemem skrajnej nędzy, jednak bieda, ubóstwo, niedostatek, brak dostępu do podstawowych środków materialnych lub do praktyk konsumpcyjnych dostarczających prestiżu, zadowolenia czy poczucia samorealizacji wciąż pozostają udziałem części ich obywateli - i wciąż stanowią istotny temat refleksji społecznej, programów politycznych i dyskursu medialnego. Media masowe mogłyby być tą przestrzenią, w której ludzie zmarginalizowani z powodów ekonomicznych odnajdują obraz własnego życia, reprezentację swoich interesów, rozwiązania własnych praktycznych i emocjonalnych problemów. Prasa, radio, telewizja głównego nurtu i nowe media interaktywne jednak interesują się biednymi w niewielkim stopniu. Nie stanowią oni bowiem ważnej grupy docelowej dla reklamy, nie zwiększają wydatnie wskaźników czytelnictwa czy klikalności, sami w sobie nie są zbyt atrakcyjnym tematem dla poszukującego rozrywki odbiorcy. Biedni niemal nie mają swoich mediów - chyba że za takowe uznać proste i prymitywne dzienniki tabloidowe i niektóre tabloidyzowane kanały telewizyjne. Zajmują się one interesami ludzi ubogich, kontrastami między biedą a bogactwem oraz przyczynami niedostatku na swój własny, charakterystyczny dla stylistyki tabloidowej sposób. Czy tabloidyzację problemu odnajdziemy także w mediach głównego nurtu? Gdzie, rozważając problem tabloidowego ujęcia problemu biedy w mediach poszukiwać jej reprezentacji i odzwierciedleń?

Przystępując do analiz reprezentacji ubóstwa w mediach przyjęto, iż swoisty wzorzec tabloidowego ujęcia problemu biedy i wykluczenia w polskich warunkach odnajdziemy w dwóch największych i najszerzej czytanych polskich dziennikach tabloidowych: „Fakcie” i „Super Expressie”.

1 W dalszej części tekstu używane są skróty: F - „Fakt”, SE - „Super Express”. Numer po skrócie oznacza numer wydania, za każdym razem podawana jest także data dzienna i miesięczna. 
Uznano, że jakościowa analiza ich zawartości powinna wskazać swoisty model prezentacji problemu w tabloidach. Przyjmując go za punkt wyjścia, można by następnie sprawdzi, czy wpływ ideologii i stylistyki tabloidu w podejściu do tematu odbija się w mediach głównego nurtu (por. Bauer 2010). A może tabloidyzacji nie odnajdziemy tam w ogóle, lub też dostrzeżemy jedynie niektóre jej komponenty?

\section{Dyskurs tabloidów, wyznaczniki tabloidyzacji}

Przypomnijmy na wstępie pokrótce charakterystyczne cechy dyskursu prasy tabloidowej. Zwrócimy przy tym uwagę że w Polsce, na stosunkowo płytkim i mało zróżnicowanym rynku prasy drukowanej, mamy do czynienia ze swoistą hybrydą gatunkową: dwa największe polskie tabloidy muszą zaspokajać rozmaite potrzeby czytelników jednocześnie. Zawieszone są zatem pomiędzy dziennikiem bulwarowym typu brytyjskiego, skoncentrowanym na tematyce politycznej i ekscesach najbardziej uprzywilejowanych grup społecznych - polityków i celebrytów, a amerykańskim tabloidem fantastycznym, donoszącym o lądowaniach kosmitów i zjawiskach nadprzyrodzonych; aczkolwiek, zauważyć można, że udział komponentów fantastycznych w treści polskich tabloidów zmniejszył się w ostatnich latach, pozostawiając więcej miejsca tematyce politycznej. W polskich warunkach pisma te zawierają także elementy typowe dla wynalezionej bodaj w Ameryce Południowej prensa popular - w przystępnej formie udzielają czytelnikom praktycznych porad, pomocnych w życiu codziennym. Udział tego typu treści w całej zawartości polskich tabloidów jest jednak stosunkowo niewielki; podjęta przez „Super Express” w pierwszych latach stulecia próba bardziej konsekwentnego stosowania formuły dziennika popularnego zakończyła się finansowym fiaskiem i powrotem do treści krwawych i skandalicznych. Klęską okazała się także próba uruchomienia gazety popularnej „Nowy Dzień" podjęta w latach 2005-2006 przez spółkę Agora.

Dwa największe polskie tabloidy różnią się stylistyką. „Fakt” jest bardziej sensacyjny, operuje większą ilością kontrastów, hiperboli i kolokwializmów, stawia w większym stopniu na silne negatywne pobudzenie odbiorców i ich zainteresowanie skandalem i plotką. „Super Express", trochę ostrożniejszy w ocenach, stylistykę ma nieco bardziej umiarkowaną. Są to jednak niuanse. Struktura tematyczna obydwu pism, sposób reprezentacji rzeczywistości oraz założenia co do relacji na- 
dawczo-odbiorczych wykazują zdecydowanie więcej podobieństw, niż różnic.

Głównym tematem tabloidu jest swoiście rozumiany skandal. Podstawowymi źródłami skandalu mają być prywatność i intymność, przemoc $\mathrm{w}$ relacjach międzyludzkich oraz nadużycia przywilejów przez uprzywilejowane grupy społeczne i jednostki. Opisywane tutaj polskie tabloidy nie pomijają plotek o życiu seksualnym i rodzinnym znanych postaci ani też krwawych, pełnych przemocy wiadomości kryminalnych, jednak najważniejszą przyczyną skandalu jest $\mathrm{w}$ ich ujęciu to trzecie; korupcja i arogancja elit politycznych zajmują w nich stosunkowo najwięcej miejsca i opisywane są przy pomocy najbardziej emocjonalnego języka.

Tabloidy operują w ramach uproszczonej, niezwykle wyrazistej aksjologii, w ramach której po stronie zła znajdują się skorumpowane, chciwe, aroganckie i wyuzdane elity - politycy, urzędnicy, częściowo także gwiazdy mediów masowych, po stronie dobra natomiast - „zwykli ludzie": bezbronni i skrzywdzeni albo oburzeni i gniewni. Swoista jest tu rola dziennikarza tabloidu. Nie przyjmuje on zdystansowanej pozycji obiektywnego informatora, stanowiącej standard (nie zawsze przestrzegany, lecz stanowiący podstawowy wyznacznik profesjonalizmu) w informacyjnych mediach głównego nurtu. Jasno i dobitnie sytuuje się po stronie „dobra”, czyli po stronie „wszystkich zwykłych Polaków”, utożsamianych z czytelnikami tabloidu, który go zatrudnia. Manifestacyjnie staje po stronie ofiar prawdziwych lub domniemanych nadużyć władzy, w razie potrzeby traktuje tę władzę szyderczo lub ironicznie, lub wskazuje czytelnikowi, przeciwko komu powinien on skierować gniew lub oburzenie. Podkreśla własną pozycję jako jedynego naprawdę dobrze poinformowanego, lub też jedynego odważnego, ośmielającego się dostarczać widzom prawdziwej wiedzy o świecie, przed czym inne media powstrzymują się bądź dlatego, że same są skorumpowane i powiązane z władza, bądź dlatego, że się tej władzy boją.

Selekcja informacji w tabloidach odzwierciedla logikę przyznającą informacjom skandalicznym prymat nad ,nudnymi”. Powstaje w związ$\mathrm{ku} \mathrm{z}$ tym konieczność takiego formatowania informacji skądinąd nie zawierających elementów skandalu, aby i one mogły zostać uznane za sensacyjne i/lub skandaliczne. Stąd prowokacje i kreowanie tak zwanych faktów medialnych oraz ambiwalentny stosunek do paktu faktograficznego - mieszanie w rozmaitych proporcjach informacji prawdziwych, stronniczych interpretacji i nadinterpretacji wydarzeń, faktów medial- 
nych, faktoidów, plotek, przypuszczeń i podejrzeń oraz całkowitych zmyśleń i urban tales.

Służy temu swoista stylistyka oraz charakterystyczne praktyki reprezentacyjne organizujące obraz. W sferze języka odnajdziemy tu przede wszystkim dowartościowanie mowy kolokwialnej. Używany jest głównie kod ograniczony, z silnym komponentem fatycznym. Konieczność szybkiego nawiązywania kontaktu z niezbyt wymagającym czytelnikiem pociaga za sobą posługiwanie się etykietami językowymi, stereotypami oraz dużą liczbą wyrażeń wartościujących, a także częste używanie bezpośredniego zaadresowania. Prowadzi to do hiperbolizacji i emocjonalizacji dyskursu, nierzadko także do włączania w jego obręb elementów melodramatycznych. Rozwiązania wizualne - sposób wykorzystania mechanizmów i konwencji patrzenia, układ typograficzny, szczegółowe rozwiązania syntagmatyczne, dobór obrazów, kolorystyka, dodatkowe wskazówki interpretacyjne wbudowane w obraz, relacje pomiędzy obrazem a podpisami i tekstem - ułatwiają zrozumienie tekstu zgodne $\mathrm{z}$ intencjami autorów, prowadzą do wzmocnienia i podkreślenia autorskiej interpretacji opisywanych zjawisk oraz umożliwiają czytelnikowi szybka, jednoznaczną orientację aksjologiczną. Dobór materiału fotograficznego w tabloidzie odzwierciedla dychotomiczny i konfliktowy wydźwięk treści. Hiperbolizacja współistnieje tu z obrazami generującymi (przy pomocy szczegółowych rozwiązań w sferze doboru elementów i syntagmy) wrażenie zwyczajności, codzienności i bliskości. Fotografie pozycjonujące swoje obiekty w natarczywym zaadresowaniu bezpośrednim sąsiadują ze zdjęciami voyeurystycznymi, odbijającymi pozycję fotografa (i widza) jako podglądacza, ukrytego i wykluczonego z relacjonowanych wydarzeń. Obrazy te maja przede wszystkim pozorowany charakter tautologiczny (sugestia pokazywania świata „takim, jaki jest”) i/lub czytelny wymiar metonimiczny (metonimie indeksujące odsyłające do „świata skorumpowanej polityki”, „wielkiego show businessu” oraz do rzeczywistości ,zwykłych ludzi”).

\section{Bieda: co mówią tabloidy}

Na tle tego względnie spójnego dyskursu, podporządkowanego jednolitej konwencji nadawczo-odbiorczej i czytelnej ideologii rozwija się w polskich tabloidach dyskurs o biedzie i bogactwie, o władzy i społecznym wykluczeniu. Przyjrzyjmy się zatem, jak wygląda „dyskurs 
biedy” w „Fakcie” i „Super Expressie” na wiosnę 2012 roku. Dla potrzeb tej diagnozy poddano analizie 12 numerów - po sześć każdego z tytułów - obejmujących tydzień od 15 do 22 kwietnia 2012 (numer weekendowy datowany podwójnie). Tekst poddano jakościowej analizie dyskursu oraz analizie retorycznej. Do analizy obrazów oraz relacji pomiędzy obrazem a innymi elementami układu typograficznego zastosowano techniki z repertuaru semiologii.

Próba może się wydawać stosunkowo niewielka, trzeba jednak zauważyć, że zagadnienie biedy i kontrastów bogaci/biedni to jeden z najważniejszych tematów dyskursu tabloidowego. Dyspersja publikacji na ten temat jest tak niewielka, że próba tygodniowa okazała się aż nadto obszerna, jak na potrzeby badań jakościowych: objęła 308 kolumn gazetowych, w których wyróżniono co najmniej 54 publikacje, spełniające zdefiniowane na etapie operacjonalizacji problemu warunki, pozwalające je zakwalifikować jako materiały poświęcone wyłącznie lub w przeważającej mierze problemowi biedy i bogactwa (dla jasności wywodu pominięto te teksty, w których problem biedy i bogactwa pojawiał się marginesowo, pretekstowo, okazjonalnie).

\section{II.1. Czym jest bieda?}

Nigdzie w badanym materiale nie odnaleziono explicite definicji biedy ani odniesień do niej wprost. Jej definiowanie jednak odbywa się - pośrednio - poprzez 1) wartościowanie warunków życia „Zwykłych” Polaków jako złych, niepewnych, niewystarczających, frustrujących oraz poprzez 2) rząd dychotomii i opozycji; w tabloidowych publikacjach dobitnie i wprost wskazuje się, kto w Polsce jest bogaty i na czym polega bogactwo oraz przeciwstawia się sposób życia bogatych życiu „zwykłego człowieka".

\section{II.2. Kto jest biedny?}

Brak definicji biedy sformułowanej wprost jest stosunkowo zrozumiały: wynika mianowicie z podstawowego założenia aksjolologicznego tabloidów, przeciwstawiającego zwykłego człowieka - elitom finansowym i politycznym, i sytuującego dziennikarzy tabloidu i redakcję w roli obrońców interesów zwykłych ludzi, czytaj - własnych czytelników. 
Stąd paradoksalne założenie: biedni jesteśmy my wszyscy, czyli - wszyscy zwyczajni Polacy, utożsamiani po prostu z czytelnikami tabloidu. Wydaje się oczywiste, że dla każdego z czytelników to, czym jest bieda, jest jasne, ponieważ jest ona udziałem „zwykłych” Polaków, ich codziennością, definiować jej zatem nie trzeba. Następuje więc niejako naturalizacja stanu ubóstwa, uznanie go za permanentny i oczywisty. Pociaga to za sobą swoistą aksjologizację niedostatku: skoro biedni jesteśmy my wszyscy, i skoro dziennikarz tabloidu to jeden $\mathrm{z}$ nas albo przynajmniej ktoś, kto utożsamia się z naszymi interesami, bieda jest po prostu przypadłością dobrych (ciężko pracujących, uczciwych) ludzi.

Tabloidowa koncepcja biedy daleka jest więc od ponowoczesnych i pokonsumpcyjnych koncepcji niedostatku typowych dla zamożnych społeczeństw kapitalistycznych, gdzie niedostatek definiuje się przede wszystkim w kategoriach względnych (jako deprywację relatywną, brak dóbr które „wszyscy inni już mają" i których posiadanie świadczy o zadowalającym statusie społecznym), jako stan marginalizacji społecznej, a także jako niemożność samorealizacji i należytej autoekspresji (Lister 2007). Według tabloidu (powszechna) bieda polega na (powszechnym) braku pieniędzy na realizację podstawowych potrzeb (w badanej próbce: jedzenia, leków, opieki medycznej, dostępu do szkolnych obiadów i opieki przedszkolnej), na stanie niepewności co do przyszłości oraz konieczności ciężkiej, wyczerpującej pracy (lub, w szczególnych przypadkach, na braku tej pracy).

\section{II.3. Reprezentacje biedy: ciężki los człowieka i arogancja władzy}

W badanym materiale wyraziście dają się zatem zauważyć dwie skonwencjonalizowane formuły reprezentacyjne, używane do pokazywania biedy: bieda jako „ciężki los zwykłego człowieka”...

„Ta wiadomość poraziła rodziców! Nie 4 złote jak dotychczas, ale minimum 6 złotych za obiad w szkolnej stołówce. [...] Dorota Rejman (34 1.) boi się, że nie będzie jej stać na obiady dla synów! [...] W takiej sytuacji jak ona są setki krakowian, dla których podwyżka cen obiadów to wydatek nie do przeskoczenia" (F 90, 17.04, wydanie lokalne).

„Tego już za wiele! Piwo zdrożeje. [...] Benzyna po 6 złotych, jajka po złotówce - Polacy z godnością znoszą kolejne podwyżki cen. Ale ta wiadomość może przelać czarę goryczy" (SE 91, 18.04). 
„Jemy suchary bo ukradli nam mięso. Zapach zrazów zwabił złodzieja do domu Ireny Brzozowskiej (38 1.) z Czachówek. Mamo, jeść mi się chce. Aż brzuszek mnie boli - mała Ala Brzozowska (5 1.) z Czachówek [...] dosłownie skręca się z głodu. Niestety, jej mama Irena $(38$ 1.) ma dla niej tylko... sucharki. - Tyle nam zostało po wizycie złodzieja - tłumaczy" (SE 93, 20.04).

„Wyniki sondażu CBOS. Boimy się biedy i oszczędzamy [...] Prawie 30 proc. Polaków uważa, że żyje w biedzie" (SE 94, 21.04).

...oraz jako „skutek złodziejstwa, korupcji i arogancji elit”.

„Minister dba o swoich ludzi. Kiedy urzędnicy będą zajadać frykasy, Polacy będą z miesiąca na miesiąc dłużej tyrać na nędzną emeryturę. Minister Władysław Kosiniak-Kamysz zgodził się na to, i jeszcze zachwala reformę. Urzędników, którzy wydłużają nam wiek emerytalny, czekają wystawne uczty! To na to będą pracować Polacy do 67. roku życia. [...] Władysław Kosiniak-Kamysz z wielkim zapałem promuje reformę emerytalna, która skazuje Polaków na pracę do śmierci" (F 91, 18.04).

\section{II.4. Kto jest bogaty?}

Bogaczami według tabloidów są w Polsce przede wszystkim politycy. Poza tym do kategorii tej należą urzędnicy (jako posiadacze wielkich osobistych majątków lub pasożyty korzystające z ,pieniędzy podatników”) oraz celebryci. Co jednak ciekawe, do klasy bogaczy kategorii mimochodem włącza się także reprezentantów wolnych zawodów - naukowców czy lekarzy, przypisując im także wygórowane żądania płacowe i pazerność.

Także tabloidowa koncepcja bogactwa nie zakłada większego niż przeciętny dostępu do realizacji potrzeb samorealizacyjnych czy też autoprezentacyjnych, ani też do udziału w konsumpcyjnym karnawale. Bogactwo reprezentowane jest tu w kategoriach ekscesu, nieumiarkowania, chciwości. Bogaci między innymi (wszystkie niżej przytoczone wyrażenia pochodzą $\mathrm{z}$ tego jednego, analizowanego tygodnia!):

„są pazerni, zgarniaja, nachapują się, żyją jak królowie, puszczają z dymem pieniądze, balują z gośćmi, zajadają się frykasami, wydają wystawne uczty",

a także:

„robią fuchy, biorą łapówki, za co tylko się dało, biorą dwie pensje za to samo, zarabiają krocie, biorą fortunę za wykłady". 
Tabloidy niezwykle konsekwentnie operują tu dokładnymi kwotami; zawsze, gdy mowa jest o zarobkach i/lub wydatkach elit politycznych, podawane są konkretne sumy. Najczęściej przytaczane są kwoty bardzo wysokie, wyraziście przemawiające do wyobraźni czytelnika. Zgodnie jednak z logiką skandalizacji, także sumy w polskich warunkach zwyczajne i dostępne, przedstawiane są jako ogromne i skandaliczne, gdy tylko dotyczą kogoś związanego z elitami politycznymi lub towarzyskimi. Jako ekscesy prezentuje się zatem nawet posiadanie rzeczy skądinąd niezbyt kosztownych i zapewne dostępnych po prostu niezbyt wyrafinowanej kulturowo klasie średniej.

„Jarosław Kalinowski skończył 50 lat. Z tej okazji, chłopski lider balował z gośćmi jak król. Wynajął zamek w Pułtusku. Na cześć jubilata pięć razy wystrzeliła armata. [...] zwykły organizator imprezy na zamku za jedną osobę musi zapłacić 100 złotych. Jednak Jarosław Kalinowski musiał wyłożyć 150 zł ze względu na specjalną kuchnię i barek" (F 90, 17.04).

„Urzędnicy ministra pracy, którzy wydłużają nam wiek emerytalny, będą zajadać się frykasami. [...] Menu ministra Kosiniak-Kamysza: Krem brokułowy albo żurek staropolski z jajkiem i kiełbasa, Pieczony dorsz faszerowany warzywami zapiekany pod beszamelem, Ziemniaki gotowane lub pieczone oraz bukiet warzyw gotowanych, Tarta z owocami [...] Biurokraci mają dostać oryginalny sok, a nie jakiś rozwodniony koncentrat" (F 91, 18.04).

„Fotoaparat za ok. 3500 złotych. Tak drogi sprzęt ma Kasia Tusk” (F 93, 20.04).

Dla semiologa szczególnie ciekawy wydaje się sposób, w jaki w badanym materiale konstruowana/reprezentowana jest postać bogacza. Nawiązuje ona bowiem do konwencjonalnych kodów reprezentacyjnych obsługujących koncept bogacza/wyzyskiwacza jeszcze w lewicującej prasie oraz w kinie popularnym dwudziestolecia międzywojennego, przejętych ochoczo przez komunistyczną propagandę PRL w połowie $\mathrm{XX}$ wieku! Bogacz/wyzyskiwacz to zatem nie tylko ktoś, kto ma wypchany portfel. Postać jego zbudowana jest z prostych, powtarzalnych, łatwych do zrozumienia indeksów władzy i pieniędzy. Zupełnie jak na propagandowych rysunkach antyamerykańskich z lat 50. ma on cygaro (!) i luksusową limuzynę. Poza tym - biżuterię (brylanty!), kosztowne drobiazgi, pije drogi alkohol - koniak lub whisky, jada w restauracjach, chodzi na bale i rauty. 
„Premier Bielecki. I on każe pracować aż do śmierci. Z cygarem w ustach zachęca do dłuższej pracy. [...] Z cygarem w ręku - jedno może kosztować nawet 50 złotych" (F 88, 15.04).

„Pięć lat dla Sawickiej za korupcję. Trzydziestoletnia whisky, pióro z diamentem i kolacja w Sheratonie (F 91, 18.04).

„Minister łapówkarz żyje jak król. Luksusowa willa, drogi samochód, drogie warszawskie restauracje" (F 91, 18.04).

Bogaczowi przypisuje się oderwanie od rzeczywistości, nieodpowiedzialność, dwulicowość. Dwie główne cechy polityka i urzędnika to jednak: nieopanowana chciwość - cecha ta powraca praktycznie we wszystkich publikacjach dotyczących bogatych...

„Tomasz Lipiec skazany. Minister sportu idzie do więzienia. Brał łapówki za co tylko się dało.[...] Strach przed karą? Poczucie wstydu? Nic z tych rzeczy - górę brała chciwość" (SE 91, 18.04).

„Skandal w dyrekcji dróg. Dwie pensje za to samo a autostrad nadal nie ma [...] Nigdzie nie zarobisz tak, jak na państwowym" (F 93, 20.04).

„Chodziło o rozpracowanie posłanki PO zachłannej na pieniądze i błyskotki” (F 91, 18.04).

„Porażka Izabeli Trojanowskiej (57 1.) Nie poleci do USA, bo jest pazerna" (SE 89, 16.04).

„Bielecki przez 6 lat, jako prezes Pekao, zarabiał około 100 tysięcy miesięcznie. A gdy trzy lata temu odchodził z banku, na otarcie łez dostał [...] thuste 8,7 miliona złotych. [...] Reforma emerytalna go nie dotyczy. Nie narzeka też raczej na brak oszczędności, bo przez ostatnie lata zarabiał w banku krocie, które wystarczą mu na dostatnie życie nawet w ogóle bez emerytury" (F 88, 15.04).

„Europosłowie na boku zarabiają fortuny. [...] Wynajmują się jako np. doradcy firm adwokackich, koncernów, lub biorą fortunę za wykłady" (F 88, 15.04).

„Na biednego nie trafiło. [...] gdy Jarosław Kalinowski był w Sejmie, zarabiał 12,5 tys. zł a teraz w Parlamencie Europejskim zgarnia prawie trzy razy tyle. Może sobie pozwolić na imprezę z okazji 50. urodzin, której i król by się nie powstydził" (F 90, 17.04).

...oraz brak zainteresowania dla zwykłego człowieka:

„Tusku! Tego życzą ci Polacy! Sława Michalak, bezrobotna: Życzę panu premierowi, żeby czasem wpadł w miejsca, gdzie mieszkają ludzie ubodzy. Krzysztof Michalak, brukarz: Życzę premierowi, by 
przynajmniej jeden dzień musiał pomyśleć, jak wyżywić moją rodzinę" (SE 94, 21.04).

„Tym zajmuje się Ministerstwo Spraw Zagranicznych. Rozdają sobie bilety na Euro 2012" (SE 88, 14-15.04).

„Obywatelu! Ten kraj jest dla nich: URZĘDASÓW I PREZESÓW! To przez nich chorzy na raka nie mają leków" (SE 88, 14-15.04).

„Kolejny szaleńczy pomysł prezesa ZUS. ZUS bawi się w bieganie. Prezes ZUS zamiast troszczyć się o emerytów, wymyśla coraz to nowe rozrywki dla swoich pracowników. Były już podróże w egzotyczne zakątki świata, kosztowne szkolenia dla najbliższych współpracowników, a nawet pomysł stworzenie chóru! [...] choć organizacja festiwalu biegów ostatecznie nie doszła do skutku, nie oznacza to wcale, że w przyszłości prezes ZUS nie wymyśli czegoś równie ekscentrycznego" (SE 94, 21.04).

„Bogacze z rządu zdecydowali: Będziemy harować do 67 lat. Będziemy harować po kres naszych sił. Ustawa boleśnie uderzy we wszystkich nas, poza ludźmi władzy. [...] Majątki członków rządu szacowane są na setki tysięcy, a nawet miliony złotych. [...] Oni nie muszą martwić się o emeryturę" (SE 94, 21.04).

„W nocy okulista ci nie pomoże, bo na państwowym zarabia mało. Nie ma komu pracować, bo specjaliści od oczu wolą zatrudniać się w prywatnych gabinetach" (F 88, 14-15.04).

„Ponad sto złotych za miesięczne wyżywienie dziecka w szkole? To bardzo możliwe! Władze miasta za nic mają dobro naszych dzieciaków" (F 90, 17.04).

\section{II.5. Kto jest winien?}

Kontrasty majątkowe pomiędzy najbiedniejszymi i najbogatszymi występują zatem w tabloidach jako przyczyna biedy, nie zaś korelat głębszych zjawisk o charakterze ekonomicznym i politycznych. Pojawia się wręcz sugestia, że gdyby najbogatszym odebrać posiadane przez nich środki, to - zwrócone nam (wszystkim normalnym, biednym Polakom) - zlikwidowałyby one biedę! Tabloidy wyraźnie wskazują zatem czytelnikowi winnych jego żałosnej kondycji, w sposób typowy dla tego gatunku personalizując konflikt społeczny i nadając obu jego stronom twarze konkretnych jednostek. Nie ma natomiast w analizowanym materiale żadnych praktycznie przyczyn systemowych. Brak tu analizy zależności i mechanizmów społecznych i ekonomicznych, generujących 
kontrasty majątkowe, nie ma też wskazówek, w jaki sposób problem ten mógłby zostać całościowo rozwiązany. Reakcją na kontrasty majątkowe mają być po prostu gniew i oburzenie, skierowane przeciwko konkretnym osobom, znanym z imienia i nazwiska i przeciwko grupom - politykom, urzędnikom, lekarzom, prawnikom, celebrytom.

\section{II.6. Bieda jako naturalne tło}

Warto zauważyć, że w badanym materiale można rzeczywiście zobaczyć obrazy fotograficzne i przeczytać narracje o prawdziwej głębokiej nędzy i wykluczeniu - jednak nie w tych publikacjach, które biedzie i niedostatkowi są poświęcone explicite. Obrazy te towarzyszą nie swoistej tabloidowej publicystyce polityczno-społecznej, lecz sektorowi faits divers oraz relacjom z rozmaitych przestępstw i wykroczeń, stanowiącym niezbędny element każdego numeru. Oto zatem pijany traktorzysta wlecze po drodze zabitego motocyklistę, rolnik gwałci własną córkę i wnuczkę, złomiarz - określony jako drań i bezbożnik - demontuje groby na cmentarzu, zazdrosny narzeczony - alkoholik przebija partnerkę nożem, lokator kradnie gaz, drobna pośredniczka nieruchomości oszukuje klientów, rolnik goni policjantów z siekierą, złodziej kradnie garnek z mięsem $\mathrm{z}$ balkonu sąsiadki... Relacje te, konstruowane zgodnie $\mathrm{z}$ tabloidową logiką hiperbolizacji, skandalizacji i aksjologicznego uproszczenia, zawierają liczne szczegóły obyczajowe, przede wszystkim z życia tak zwanej Polski powiatowej. Powtarzają się w nich nawiązania do licznych patologii życia rodzinnego i społecznego, w szczególności do alkoholizmu, przemocy, nadużyć seksualnych i drobnego złodziejstwa tak powszechnego, że jest już praktyką powszechną. Towarzyszą im fotografie, na których rzeczywiście obejrzeć możemy nędzne, zdemolowane domy, mieszkania, baraki; biednie ubranych, zaniedbanych, wyniszczonych ludzi; zdewastowany krajobraz małych miasteczek i wsi. Taki jest kontekst doniesień o nastolatkach, którzy dla paru groszy zatłukli sąsiada, o kłótni między rodzeństwem zakończonej zabiciem brata przez siostrę czy o mężczyźnie, który zamordował, poćwiartował i ugotował własną matkę. W tym jednak miejscu kończy się inkluzywność tabloidowych narracji z życia wziętych. Czytelnik jest wzywany do odbioru tych opowieści niejako z zewnątrz, do przyjęcia postawy zdumienia, oburzenia, obrzydzenia, znika natomiast sugestia, że bohaterowie opisywanych przez tabloid wydarzeń należeć by mogli do nas, czytelników - zwykłych biednych ludzi. Nie ma tu żadnych ocen 
sytuacji materialnej, w której znajdują się bohaterowie tych wydarzeń, tak ofiary, jak i sprawcy - nie mówi się zatem o biedzie, niedostatku, ubóstwie, lecz najwyżej o fatum i losie. W żadnym wypadku nie ma mowy o tym, że patologie społeczne, opisywane jako kontekst czy podłoże opisywanych zbrodni i wykroczeń mogą pozostawać w jakiejś wzajemnej zależności z biedą i materialnym oraz społecznym wykluczeniem i zaniedbaniem, w jakim (co można wnioskować na podstawie ilustracji i opisu tła społecznego) ci bohaterowie żyją.

\section{II.7. Odrębność tabloidów kobiecych}

Warto zauważyć, że taka postawa w stosunku do zjawiska biedy i kontrastów bieda/bogactwo - gniew, wściekłość, zawiść, frustracja - typowa jest przede wszystkim dla polskich tabloidów głównego nurtu. Dokonany niezależnie od opisywanej analizy ogląd prasy tabloidowej dla kobiet - magazynów plotkarskich i pism kobieco-poradnikowych z najniższej półki, a także ilustrowanych kobiecych dodatków do „Faktu” i „Super Expressu” ujawnia odmienny stosunek do kwestii niedostatku i wykluczenia. Bieda jest tu naturalizowana i normalizowana, jednak nie szuka się jej przyczyn, ale w sposób praktyczny poszukuje rozwiązania niesionych przez nią problemów przy pomocy osobistej zaradności, inicjatywy oraz wzajemnej, międzyludzkiej pomocy i wsparcia - w szczególności wsparcia udzielanego sobie wzajemnie pomiędzy kobietami. Narracje o rozmaitych kryzysach w ludzkim (najczęściej jednak kobiecym) życiu dotyczą tu utraty pracy lub jej braku, konieczności wyżywienia rodziny lub samodzielnego utrzymania dzieci w sytuacji ograniczonych środków, potrzeby zebrania pieniędzy na leczenie czy edukację itp. Zazwyczaj nie pokazują kontrastu między światem biednych i bogatych, wskazuje się w nich natomiast konstruktywne rozwiązania problemów, najczęściej dzięki osobistej zaradności bohaterek i/lub pomocy innych ludzi. Stanowiące integralną część tabloidów kobiecych plotki o celebrytach i gwiazdach ukazują niekiedy konsumpcyjne ekscesy (kosztowną garderobę i kosmetyki, wille i pałace, jachty, egzotyczne wakacje), pozbawione są jednak motywu zawiści czy obwiniania kogokolwiek. Dostarczają głównie eskapistycznych przyjemności, niekiedy zaś - porad umożliwiających naśladownictwo w ramach własnych ograniczonych środków (na przykład jak skopiować ubiór znanej gwiazdy za o wiele mniejsze pieniądze). 


\section{Bieda: co mówią media głównego nurtu?}

Opis reprezentacji biedy i wykluczenia w mediach masowych stanowił jeden z elementów wspólnej analizy praktyk konsumpcyjnych i roli w nich mediów dokonywanej w latach 2011-2012 przez studentów Instytutu Dziennikarstwa i Komunikacji Społecznej UJ w Krakowie w ramach prowadzonego przez autorkę niniejszego tekstu seminarium specjalistycznego Media i praktyki kulturowe społeczeństwa konsumpcyjnego.

W mediach głównego nurtu bieda stanowi przede wszystkim temat publicystyki społecznej i reportażu interwencyjnego - istotny, lecz bynajmniej nie najważniejszy i w żadnym wypadku nie najczęściej poruszany. Poszukując wzorca jej prezentacji sięgnąć więc można na przykład do publicystyki i reportażu społecznego w prasie codziennej (cykl Oto Polska właśnie w „Gazecie Wyborczej”, reportaże i materiały interwencyjne w prasie regionalnej i lokalnej) oraz w pismach opinii (reportaże społeczne w „Polityce”, w mniejszym zakresie we „Wprost” czy „Newsweeku"). W telewizji głównego nurtu obrazy biedy i konsumpcyjnego/społecznego wykluczenia odnajdziemy w reportażach interwencyjnych (np. Uwaga w TVN, Zawsze po 21 w TVP), a także w społecznych newsach w serwisach informacyjnych. Czy sposób prezentowania biedy i biednych w quality media wykazuje jakieś pokrewieństwa z dyskursem tabloidów? Czy może jest w stosunku do nich odmienny? A może da się obronić tezę o pewnych szczególnych aspektach tabloidyzacji problemu?

\section{III.1. W poszukiwaniu tabloidyzacji}

Analizując obrazy biedy w quality media, trudno już na pierwszy rzut oka nie zauważyć komponentów tabloidyzacji - upodobnienia doboru treści, form, języka, obrazu świata w mediach głównego nurtu do treści, formy, języka, obrazu świata typowego dla prasy tabloidowej (Sparks, Tulloch 2000). Przy bliższej analizie okazuje się jednak, że są tu również liczne odrębności, tabloidyzacja zaś dotyczy jedynie niektórych aspektów tej tematyki.

Elementów paradygmatu tabloidowego w mediach głównego nurtu szukać można $\mathrm{w}$ treści, w rozwiązaniach formalnych $\mathrm{w}$ sferze języka i obrazu, w retoryce i stylistyce, a także w aksjologii i sposobie konstruowania obrazu świata oraz konceptualizacji zjawisk. Jeśli przyjąć, że ta- 
bloidyzacja to podporządkowanie form, treści, struktury, języka mediów masowych potrzebie sensacji i negatywnego pobudzenia emocjonalnego widzów (co jest podstawowym założeniem relacji nadawczo-odbiorczej w prasie tabloidowej głównego nurtu; Lisowska-Magdziarz 2008: 199 i dalsze), to o tabloidyzacji ujęcia problematyki biedy w mediach głównego nurtu może świadczyć przedstawianie biedy zgodne z logiką skandalizacji, hiperbolizowane i emocjonalizowane - w taki sposób, że pobudzenie emocjonalne widzów ważniejsze jest od potrzeby dostarczania wyjaśnień i rozwiązań. Można się go dopatrywać w uproszczeniach aksjologicznych i stereotypizacji postaci, grup, miejsc, zjawisk z biedą związanych. W sferze stylistyki poszukiwać tu by należało języka typowego dla tabloidu (kod ograniczony, emocje i hiperbole, potoczność) oraz rozwiązań melodoksyjnych, upodobniających język mediów do emocjonalnego, subiektywnego, pełnego kontrastów, skrajności i mocnych wartościowań języka melodramatu. W mediach elektronicznych na tabloidyzację wskazywać mogą typowe dla tabloidów rozwiązania wizualne i wizualno-dźwiękowe: prostota obrazu, bezpośrednie zaadresowanie, ikoniczne i/lub dźwiękowe wskazówki interpretacyjne i wzmocnienia wbudowane w obraz.

\section{III.2. Kto jest biedny?}

Podobnie jako „Super Express” i „Fakt”, quality media także wskazują konkretne obszary biedy i personalizują problem, jako głównych biednych w polskim społeczeństwie wskazując cztery grupy najbardziej na ubóstwo i biedę narażone oraz najczęściej ponoszące jego konsekwencje. Biednymi bohaterami publicystycznych materiałów w mediach głównego nurtu są: dzieci, ludzie starzy, osoby przewlekle lub terminalnie chore $\mathrm{i}$ ich opiekunowie oraz szeroko rozumiana sfera marginesu społecznego. Te kategorie często się na siebie w pewnej mierze nakładają. Znamienna jest jednak różnica perspektywy. O ile z punktu widzenia tabloidów biedni jesteśmy „my wszyscy” - zwykli, uczciwi, pracowici Polacy, o tyle biedni w perspektywie mediów głównego nurtu to częściej nie „my”, lecz „oni” - ktoś widziany od zewnątrz, z punktu widzenia oglądającej go, reprezentującej go i opisującej jego sytuację instytucji medialnej, która dostarcza o nim wiedzy widzowi/czytelnikowi także patrzącemu nań z zewnątrz. Instytucje te jednocześnie jawnie, explicite proponują temu widzowi ramę konceptualną i interpretacyjną 
pokazywanej sytuacji i postaci, a bardzo często także proponują zaangażowanie się w poprawę losu poszkodowanego.

\section{III.3. Czym jest bieda?}

Podobnie jak w tabloidach, i tutaj łatwo dostrzec czytelną definicję biedy: ma ona swoją konkretną twarz, życiorys, miejsce występowania.

Stałym elementem tego portretu biednego Polaka jest wyeksponowana nędza i brzydota otoczenia. Powtarzają się obrazy „złych dzielnic” i nędznych warunków mieszkaniowych ludzi; uwaga kamery czy też opisującego biedę dziennikarza skupia się na szczegółach - zagrzybionych ścianach, sufitach z zaciekami, rozgrzebanych łóżkach, brudnych naczyniach, połamanych meblach, zabłoconych i zaśmieconych podwórkach. Biednemu Polakowi brak podstawowych rzeczy, koniecznych do życia - butów, leków, kredek i podręczników dla dzieci, węgla na zimę i ciepłej wody w kranie, co uwarunkowane jest oczywiście brakiem pieniędzy. Pojawiają się wątki niedostępności leczenia i rehabilitacji oraz niedostępności edukacji dla dzieci - ale także niedostępności rozrywek czy niemożliwości samorealizacji i samorozwoju. Znamienne, że o ile tabloidy dokonują normalizacji i naturalizacji biedy i niedostat$\mathrm{ku}$, o tyle media głównego nurtu w swym ujęciu problemu biedy wychodzą od (implikowanej, ale jednak obecnej i łatwej do odczytania) idei deprywacji relatywnej i porównawczej. To nie „wszyscy” są biedni, lecz biedni są bohaterowie konkretnych publikacji, bo nie stać ich na to, co „wszyscy” w XXI wieku, w państwie kapitalistycznym, w społeczeństwie konsumentów, w Europie już mają. Występuje tu zatem założenie o w pewnej mierze znormalizowanym i naturalnym standardzie życia, który powinien być udziałem każdego - i, w domniemaniu, jest rzeczywiście udziałem widza/czytelnika tych publikacji, należącego najczęściej do klasy średniej, ale nie utożsamiającego się z bohaterem medialnych narracji o konsumpcyjnym wykluczeniu.

III.4. Reprezentacje biedy: problem egzystencjalny, patologia, egzotyka, estetyka, sprawa do załatwienia

Taka definicja biedy i sytuacji ubóstwa generuje nieco inne konceptualizacje biedy $\mathrm{w}$ mediach mainstreamowych, niż $\mathrm{w}$ tabloidach co- 
dziennych. Owszem, i tutaj także znajdziemy niekiedy wizję biedy jako „losu”, „przeznaczenia”, „fatum” prześladującego jednostki; bieda ma wówczas być motywem do zamyślenia nad losem i nad głębokimi, nieodwracalnymi konsekwencjami ludzkich wyborów życiowych. Ramy konceptualne i towarzyszące im skonwencjonalizowane strategie reprezentacyjne częściej jednak ujmują biedę jako „patologię społeczną” - samą w sobie lub istotny korelat innych patologii, w szczególności alkoholizmu i przemocy rodzinnej. Media wpisują się w ten sposób w dobrze utrwalone społeczne stereotypy, dotyczące ubogich i ubóstwa (Klich 2009).

Pokazują biedę także jako swoistą „,egzotykę”. Warto przypomnieć, że mówimy tu cały czas o biedzie polskiej, nie o narracjach dokumentalnych dotyczących Afryki czy południowoamerykańskich faweli. W tak konceptualizowanych ujęciach biedy strategie wizualne i językowe reprezentacji nędzy rodzimej są jednak podobne do tych, których używa się pokazując Trzeci Świat. Generują one możliwość wojeryzmu, skojarzoną ze współczuciem i rodzajem egzystencjalnego zdumienia nad warunkami, w jakich mogą żyć ludzie.

Podobne emocje mogą towarzyszyć ujęciu biedy jako swoistego ,projektu estetycznego". Obrazom zdegradowanej ludzkiej egzystencji towarzyszy wówczas żal nad „znikającym światem” na przykład warszawskiej Pragi czy śląskich familoków. Materiały dziennikarskie, w których biedę pokazuje się w taki sposób przywołują często wątek szczerości, prawdziwości relacji międzyludzkich, wzajemnej pomocy i solidarności, które mają się pojawiać w zbiorowościach ludzi ubogich, pozbawionych dostępu do konsumpcyjnego blichtru (czyżby biedny był tu czymś w rodzaju opisywanego przez Rousseau szlachetnego dzikusa?).

Częściej jednak bieda ujmowana jest jako ,problem do załatwienia”: stanowiąc wynik ludzkiej bezduszności, biurokracji i wadliwego działania instytucji samorządowych i państwa opiekuńczego, ma swoich winowajców, łatwe (stosunkowo) do usunięcia przyczyny i może zostać zlikwidowana w wyniku przyjęcia konkretnych rozwiązań oraz wsparcia, którego biednemu udzieli medium masowe - poprzez zwrócenie uwagi na jego sytuację, interwencje prawne i organizacyjne, dostarczenie środków materialnych, najczęściej zaś poprzez mobilizację do pomocy widzów i czytelników. 


\section{III.5. Kto jest winien?}

Media mainstreamowe, podobnie jak tabloidy, wskazują winowajców ubóstwa. Winna jest bezduszność instytucji, przepisów, a często realizujących te przepisy konkretnych ludzi. Nierzadko winni są też sami biedni. Bieda może bowiem wynikać z patologii (alkoholizmu, narkomanii, lenistwa, bierności) i jest w pewnej mierze wynikiem wyboru - uporu w trwaniu przy szkodliwych nawykach życiowych, generujących ubóstwo.

Niezależnie od ramy konceptualnej, bieda bardzo często prezentowana jest $\mathrm{w}$ analizowanych publikacjach $\mathrm{w}$ stylistyce melodoksyjnej czy wręcz melodramatycznej. Wiele tu gwałtownych uczuć, rozpaczy, łez podpatrywanych i prezentowanych widzowi dla jego własnego poruszenia i wojerystycznej przyjemności. Istotne są proste nauki moralne i wyrazista aksjologia, zgodnie z którą dobro musi być nagrodzone, a życiowe perypetie ludzi słabych i biednych powinny, o ile tylko świat jest sprawiedliwy, skończyć się happy endem.

Ponieważ ubóstwo nie jest tu ujmowane jako stan naturalny i oczywisty, jego obrazom towarzyszy często przesłanie o możliwości naprawy czy rozwiązania problemu. Tkwi ono w zmianie konkretnych, szczegółowych rozwiązań prawnych; w zmianie postaw i nastawień konkretnych, odpowiedzialnych za te rozwiązania ludzi (podobne do tabloidowego jest tu przeświadczenie, że ludzkiej biedzie winni są urzędnicy); oraz w ludzkiej solidarności, okazywanej jednak tym razem nie pomiędzy samymi biednymi, lecz wyrażonej we wpłatach i darach od czytelników i widzów. Jest to w sumie logiczne i zgodne z przedmiotowym raczej, niż podmiotowym traktowaniem biednego przez mainstreamowe media. Przy okazji zaś podkreśla zewnętrzną, hierarchicznie nadrzędną pozycję widza w stosunku do opisywanego/oglądanego przedmiotu - biednego, oraz daje przyjemności społeczności, współczucia i partycypacji. To ostatnie jest bardzo ważne w sytuacji, gdy cały model użytkowania mediów nabiera coraz bardziej partycypacyjnego charakteru.

\section{III.6. Tabloidyzacja biedy?}

Ujęcie problemu ubóstwa w mediach głównego nurtu nie jest zatem tożsame z tym, które odnaleźć możemy w samych tabloidach. Możemy natomiast mówić o przejęciu pewnych środków i sposobów obrazowania. 
Podobieństwa i zapożyczenia estetyki i stylistyki tabloidowej wyrażają się w używanych środkach językowych - w szczególności w używaniu etykiet i stereotypów językowych, w hiperbolizacji i emocjonalizacji języka, w stosowaniu środków melodramatycznych, jednak bez typowej dla języka tabloidowego potoczności i agresji.

Strategie wizualne także wykazują liczne pokrewieństwa do tabloidów: jest tu personalizacja i indywidualizacja biedy, jest budowanie obrazów biedy na opozycjach i dychotomiach. Odmienny jest natomiast rodzaj wojeryzmu w podejściu to biednego - obiektu oglądu. W tabloidowej prasie praktyki wojerystyczne dotyczą przede wszystkim, jeśli nie wyłącznie, elit - podglądani są politycy i celebryci. Zdarzają się też wojerystyczne ujęcia skandali naturalnych - obrazy chorobliwych deformacji ludzkiego ciała, ofiar wypadków, przerażającej przemocy ludzkiej lub naturalnej zapewne dostarczają audytoriom tabloidów tego typu dwuznacznych przyjemności. Marne warunki życia tak zwanego zwykłego człowieka nie są jednak przedmiotem praktyk wojerystycznych, być może dlatego, że ten człowiek to w domniemany sposób „każdy czytelnik". W mediach głównego nurtu natomiast człowiek ubogi ze swoją nędzą materialną, zaniedbaniem osobistym, chorobami, nieporadnością życiową jest przedmiotem skrupulatnego oglądu. Szczegóły jego egzystencji, estetyzowane, egzotyczne, przerażające, dziwaczne to jedna $z$ atrakcji publikacji na temat biedy. Ich pokazanie nierzadko stanowi warunek, dzięki któremu przedmiotowi publikacji udzielona zostanie pomoc.

Tabloidy i media głównego nurtu różnią się co do sposobu, w jaki definiują przyczyny biedy, wspólny jednak jest brak systemowych rozwiązań i personalizacja przyczyn. Wspólna jest także prostota aksjologiczna - choć odmiennie jest tu definiowana rola medium masowego. W tabloidach opisuje się problem od wewnątrz i każe być dziennikarzowi ,jednym z nas”. W quality media dziennikarz jest usytuowany jako reprezentant instytucji medialnej, w pozycji zewnętrznej i hierarchicznie nadrzędnej zarówno w stosunku do przedmiotu oglądu, jak do widza/czytelnika, z którym jednak dziennikarz ten ma więcej wspólnego, niż z przedmiotem opisu.

Można zatem w narracjach o ubóstwie i portretach biednych w quality media odnaleźć podobieństwa, pozwalające uzasadnić twierdzenia o tabloidyzowaniu tego problemu. Nie można jednak uznać, że jest tu tożsamość; tabloidyzacja wyraża się $\mathrm{w}$ przejęciu pewnych środków formalnych, przy zachowaniu jednak odmiennego zaadresowania i odrębnych konceptualizacjach samego problemu. 


\section{Media, w których bieda nie istnieje}

Obydwa ujęcia problemu biedy i wykluczenia nie powinny być analizowane bez umiejscowienia w kontekście komunikacyjnym, kulturalnym i społecznym. Medialne narracje o ubóstwie - tabloidowe i nietabloidowe - stanowią część szerszego doświadczenia mediów masowych w konsumującym społeczeństwie kapitalistycznym. Główną komponentą tego doświadczenia nie jest ani poszukiwanie źródeł konfliktu społecznego, ani współczucie i pragnienie społecznej interwencji, lecz - rozrywka. Treść zaś mediów urozrywkowionych, stawiających na pozytywne pobudzenie emocjonalne, rozbawienie, dostarczenie przyjemności estetycznej odbiorcy jest określana wartościami o charakterze konsumpcyjnym. Opisywane narracje i obrazy występują więc na tle zasadniczego szerokiego i bardzo bogatego kontekstu, który stanowi advertainment: rozrywka w konwergentny sposób zlewająca się, przenikająca i splatająca $\mathrm{z}$ reklamą.

Treść rozrywkowych mediów komercyjnych - magazynów ilustrowanych, portali internetowych, cała olbrzymia sfera telewizyjnej rozrywki, ale także kultury wysokiej, edukacji, informacji przedstawia konsumowanie jako źródło szczęścia i jako cel, do którego jednostka może, powinna, wręcz musi dążyć. Media głównego nurtu pokazują, że praktycznie wszyscy realizują właśnie taki model życia. Mainstreamowe media rozrywkowe stają się w ten sposób narzędziem normalizacji i naturalizacji konsumpcjonizmu jako powszechnego, społecznie legitymizowanego, akceptowanego, oczywistego stylu życia. Okazują się także narzędziem konsumpcyjnego nacisku i wytwarzają stan nieustannego niepokoju statusowego. Kupowanie, posiadanie, prezentowanie rzeczy jest w tym ujęciu celem samym w sobie, źródłem zadowolenia, radości, przyjemności estetycznej, warunkiem utrzymywania społecznego prestiżu i dobrych stosunków międzyludzkich, a także najbardziej rozpowszechnionym rodzajem kulturalnej działalności człowieka. Jest też narzędziem samorealizacji i autoprezentacji. Kultura konsumpcyjna nie pozostawia wątpliwości: autokreacja i atrakcyjne prezentowanie siebie to niesłychanie ważne komponenty bycia członkiem społeczeństwa. Samorealizacja i poczucie pełni nie mogą być osiagnięte bez praktyk autokreacyjnych. Niezbędne do tego są media i kompetencja w używaniu dóbr konsumpcyjnych oferowanych przez rynek. Hedonizm staje się tutaj normą, media wskazują jego wzorce i postacie, które osiagnęły w nim swoiste mistrzostwo. Istnieje też oczywiście założenie że konsumowanie, nawet 
jeśli w zróżnicowanym zakresie, jest w gruncie rzeczy udziałem wszystkich. W tym świecie wszyscy mają pieniądze. Wszyscy posiadają dostęp do praktyk konsumpcyjnych. Wszyscy doskonalą umiejętność wyboru rzeczy i wszyscy są tym zainteresowani. Gdyby media rozrywkowe w ogóle zajmowały się ubóstwem i wykluczeniem, definicja biedy dotyczyłaby niewątpliwie braku możliwości uczestnictwa w powszechnym festiwalu konsumpcji, a zatem braku możliwości podejmowania prestiżowych, przyjemnych i dających doznanie samoaktualizacji praktyk postkonsumpcyjnych. Nie-konsument jest tu jednak zmarginalizowany tak dalece, że niemal w ogóle się o nim nie wspomina.

Opisy i obrazy ubóstwa i biedy występują więc w pewnych wydzielonych wyspach czy enklawach, stanowią zaledwie stosunkowo niewielkie wtręty do głównej narracji, która jest opowieścią o zasobnym, zmediatyzowanym, ludycznym i hedonistycznym społeczeństwie konsumentów. $\mathrm{W}$ tej narracji, poza wydzielonymi enklawami publicystyki społecznej i dziennikarskiej interwencji, biedni po prostu nie mają swego głosu, ponieważ nie występują. W rozrywkowym mainstreamie mediów masowych bieda jest nieobecna. Łatwo zrozumieć, dlaczego przy jej pokazywaniu, jeśli już w ogóle się o niej napomyka, trzeba się uciekać do środków tabloidowych: model odbioru, potrzeby, style interpretacji audytoriów kształtowane są i trenowane na mediach rozrywkowych. Żeby się przebić do uwagi audytorium, nie zniechęcić go i zaciekawić, trzeba się wpisać w potrzeby widza poszukującego głównie rozrywki, atrakcji, stymulacji emocjonalnej. Trudno się oprzeć refleksji, że takie usytuowanie tematu ubóstwa i wykluczenia w głównym nurcie mediów w metonimiczny sposób odzwierciedla sytuację samego biednego - nie-uczestnika, nie-konsumenta, w całej strukturze społeczeństwa konsumpcyjnego. Jest on tutaj obecny, ale zmarginalizowany. Nie ma własnego głosu ani nie przyznaje mu się podmiotowości (por. Klich 2009). Może być przedmiotem działań innych, adresatem współczucia, pomocy, czasem pouczeń i rad, obiektem polityk społecznych i przedmiotem dyskusji ważnych gremiów, jednak szybko znika z pola widzenia uczestników konsumpcyjnego karnawału, zajętych gromadzeniem dóbr, ich kontemplowaniem, porównywaniem i statusową prezentacją, poszukiwaniem dystynkcji i przyjemności. To smutny paradoks: pogardzane i ambiwalentnie, jeśli nie wręcz negatywnie oceniane tabloidy okazują się w tym pejzażu jedynymi mediami masowymi, które ubóstwu i związanym z nim frustracjom konsekwentnie poświęcają czas i uwagę. A że czynią to na swój własny, bardzo jednostronny i agresywny sposób, to już zupełnie inna sprawa. 


\title{
Bibliografia
}

Bauer Z., Twój głos w Twoim domu: cztery typy tabloidyzacji, w: Tabloidyzacja języka i kultury, red. I. Kamińska-Szmaj, T. Piekot, M. Poprawa, Wydawnictwo Uniwersytetu Wrocławskiego, Wrocław 2010.

Sparks C., Tulloch J., Tabloid Tales. Global Debates Over Media Standards, Rowman \& Littlefield, Oxford 2000.

Klich A., Polska bieda poniżona. Rozmowa z prof. Elżbieta Tarkowska, „Gazeta Wyborcza" 7 września 2009.

Lisowska-Magdziarz M., Media powszednie. Środki komunikowania masowego i szerokie paradygmaty medialne w życiu codziennym Polaków u progu XXI wieku, Wydawnictwo Uniwersytetu Jagiellońskiego, Kraków 2008.

Lister R., Bieda, Sic!, Warszawa 2007.

\section{Presentation of poverty and social exclusion in tabloids and the mainstream media}

\begin{abstract}
Summary
While modern, capitalist consumer societies have solved the problem of extreme poverty to a large extent, indigence, destitution, the scarcity or lack of access to basic financial means or consumer practices that provide prestige, satisfaction or a sense of self-fulfillment continue to be experienced by a portion of society and constitute a significant theme of social reflection, political platforms and media discourse. The mass media could provide an arena where people who are economically marginalized could find an image of their own existence, the representation of their interests, and solutions for their practical and emotional problems. However, the mainstream press, radio, and television, as well as the new interactive media, are interested in the poor only to a limited degree. The poor have almost no media at all, unless simplistic and primitive tabloid dailies and some tabloidized television channels are considered as such. The question can be posed, then, of whether their problems are tabloidized also in the mainstream media, and where to search for the presentation and illustration of poverty when considering the issue of the tabloidization of poverty in the media.
\end{abstract}


